\title{
Coralliophila from Grand Cayman: Specialized coral predator or parasite?
}

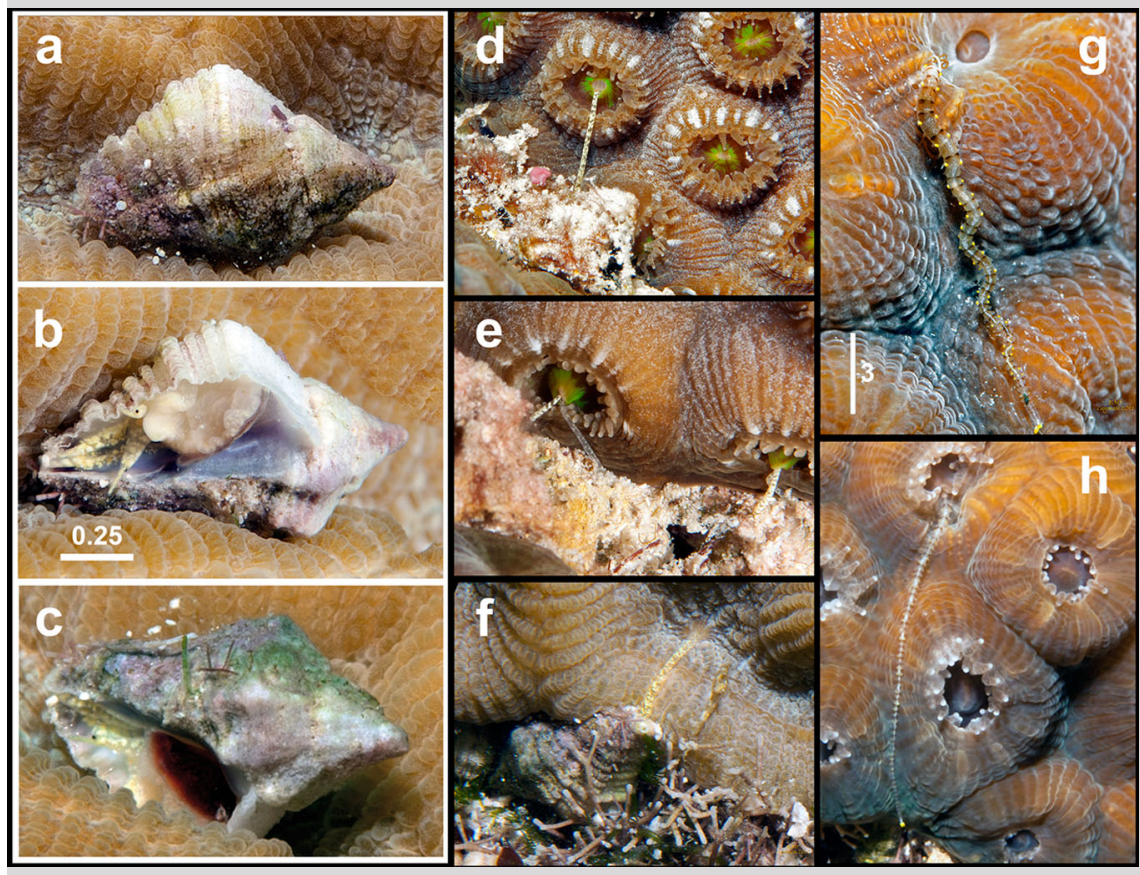

Fig. 1 Coralliophila caribbea. a Upper view. b Lower view. c View showing operculum (b, c same scale as a). d Proboscis inside a polyp. e Two specimens, each proboscis inside same polyp. f Feeding directly though coral tissues. Proceraea sp. g Near a polyp oral opening. h Worm with its head inside the oral opening
Species of Coralliophila are well-known cnidarian associates. Coralliophila clathrata, an obligate symbiont of the colonial zoanthid sea anemone Palythoa, feeds on nematocysts and zooxanthellae sloughed off in the host mucus (Robertson 1980). Coralliophila abbreviata rapidly consumes coral tissues causing substantial colony mortality. Coralliophila violace remains sedentary and taps into coral energy reserves, a "prudent", sessile feeding strategy that allows the snails to feed without moving over long periods, maximizing energy exploitation while minimizing coral damage and mortality (Oren et al. 1998).

We found numerous specimens of Coralliophila caribbea (Fig. 1a-c) on Montastrea cavernosa (only coral observed) at Grand Cayman Island. This snail feeds by introducing its proboscis through the polyp's oral opening (Fig. 1d,e) or, less frequently, through the coral epidermis (Fig. 1f), as previously observed for $C$. abbreviata (Miller 1972). Also a "prudent" strategy, this would allow sessile

feeding for extended periods. Together with the presence of zooxanthellae in the digestive tract (Miller 1972), it suggests utilization of coral tissues and energy reserves, not kleptoparasitism (i.e., stealing food from polyps). In turn, the lack of feeding scars on $M$. cavernosa suggests a feeding strategy that is closer to parasitism than to specialized predation.

A similar behavior was observed in an undescribed species of autolytine polychaete (Proceraea sp.). It appears to live in the substrate surrounding the coral and feeds by inserting its head through the oral opening of the polyps (Fig. 1g, h). With two unrelated species apparently exploiting the same resources, we argue that energy reserves may be present in many other corals and exploited by Coralliophila and perhaps other scleractinian associates.

\section{References}

Miller AC (1972) Observations on the associations and feeding of six species of prosobranch gastropods on anthozoans. Atoll Res Bull 152:4-5

Oren U, Brickner I, Loya Y (1998) Prudent sessile feeding by the corallivore snail Coralliophila violacea on coral energy sinks. Proc R Soc Lond B Biol Sci 265:2051-2055

Robertson R (1980) Epitonium millecostatum and Coralliophila clathrata: two prosobranch gastropods symbiotic with Indo-Pacific Palythoa (Coelenterata: Zoanthidae). Pac Sci 34:1-17

D. Martin $(\square) \cdot$ J. Gil

CEAB-CSIC, Accés a la Cala St Francesc 14, 17300 Blanes, Catalunya, Spain

e-mail: dani@ceab.csic.es

C. Abgarian

5420 Meadowcrest Dr, Ann Arbor, MI 48105, USA

E. Evans - E. M. Turner Jr.

64 Scugog Street, Bowmanville, ON L1C3J1, Canada

A. Nygren

Sjöfartsmuseet Akvariet, Karl Johansgatan 1-3, 41459 Göteborg, Sweden

Received: 8 May 2014/ Accepted: 4 July 2014/Published online: 24 July 2014

Coral Reefs (2014) 33:1017

(C) Springer-Verlag Berlin Heidelberg 2014

DOI $10.1007 /$ s00338-014-1190-x 